\title{
Accumulation of heavy metals in an ecosystem influenced by zinc-plant emissions
}

\author{
ZUZANNA CZUCHAJOWSKA, ELZBIETA LOREK, TERESA STRACZEK
}

Department of Plant Ecology, Institute of Botany, Silesian University, ul. Jagiellońska 24, 40-032 Katowice, Poland

(Received: September 25, 1979)

\begin{abstract}
Accumulation of $\mathrm{Pb}, \mathrm{Zn}, \mathrm{Cd}, \mathrm{Mn}, \mathrm{Fe}$ and $\mathrm{Mg}$ reaching the selected ecosystem in the dust emitted by a zinc-mill, was estimated in the leaves of Pinus silvestris, Vaccinium myrtillus and Vaccinium vitis-idaea, the main plant components of the system, and in the five upper soil layers. The values of metal concentration were different for the three considered species and showed-for each of them-dependence on the pollution degree of the stand. This regularity concerned $\mathrm{Pb}, \mathrm{Zn}, \mathrm{Cd}$ and $\mathrm{Mn}$ but not $\mathrm{Fe}$ and $\mathrm{Mg}$. A significant positive correlation exists between the content of $\mathrm{Pb}, \mathrm{Zn}$ and $\mathrm{Cd}$ in the soil and their concentration in leaves, the correlation for $\mathrm{Mn}$ is significant but negative. Manganese in leaves proved to be an antagonist in respect to the other metals.
\end{abstract}

\section{INTRODUCTION}

Zinc- and lead-mills are the source of intensive emissions, containing heavy metals which are particularly dangerous pollutants. It is the reason why this type of emissions was investigated in respect to their influence on soil ( $\mathrm{J} \circ \mathrm{hn}$ et al., 1975), on the air (Dorn et al., 1976) and on plants ( $\mathrm{Kaz}$ i mierczakowa, 1975). The present paper considers all these objects as components of an ecosystem, the main plant participants of which were the species Pinus silvestris predominating among the trees, and Vaccinium myrtillus and Vaccinium vitis-idaea the two principal components of the herb layer. The content of $\mathrm{Pb}, \mathrm{Zn}$, $\mathrm{Cd}, \mathrm{Mn}, \mathrm{Fe}$ and $\mathrm{Mg}$ was estimated in the assimilating parts of these species. Vertical distribution of these elements in the five soil layers and in the dustfall at two altitudes was also determined.

The ability of metal accumulation by the investigated species in respect to the location of a stand was investigated. The second problem 
was: how the accumulation of toxic metals in the soil and their concentration in the dustfall influence their uptake. Among these elements $\mathrm{Zn}, \mathrm{Mn}, \mathrm{Fe}$ and $\mathrm{Mg}$ are necessary for plant metabolism, while the necessity of $\mathrm{Pb}$ and $\mathrm{Cd}$ has not been considered so far.

\section{MATERIAL AND METHODS}

The investigations were carried out in four selected stands in 1977/ 178. Three of them, strongly influenced by a zinc-plant operating for many years at Miasteczko Sląskie, Upper Silesia, were situated at gradually increasing distances from the emitter, in the direction of prevailing winds; the $\mathrm{K}$ (Z̈yglinek), L (Brynica I) and M (Brynica II) stands $-0.9,2.5$ and $5.0 \mathrm{~km}$ from the zinc-plant. The fourth stand C (Kokotek) represented a control area in the forest district Lubliniec, relatively pollution-free, at a distance of $24 \mathrm{~km}$ from the center of emission. The polluted ecosystem represented a fresh pine forest in which the trees of Pinus silvestris were of equal age of about 20 years. In these stands there was a constant process (very advanced for the $\mathrm{K}$ stand) of thinning out owing to the influence of emissions. The cleared areas in which the intensity of light reaching the forest floor strongly increased, were becoming gradually dominated by both Vaccinium species, Vaccinium myrtillus being gradually ousted by Vaccinium vitis-idaea.

The soil samples were collected three-times during the whole research period, with the aid of a soil drill of $10 \mathrm{~cm}$ diameter, plunged to a depth of $25 \mathrm{~cm}$, from different spots, rather uniformly distributed in the investigated area. Individual samples were divided into five layers: $0-5,5-10,10-15,15-20$ and $20-25 \mathrm{~cm}$, and mixed samples were prepared, composed of 25-30 samples of any layer. The air-dry soil of every layer, sieved on a 2-mm sieve, was used to determine the $\mathrm{pH}$ values in $\mathrm{H}_{2} \mathrm{O}$ and $\mathrm{KCl}$ and the buffer capacity in $0.025 \mathrm{~N} \mathrm{H}_{2} \mathrm{SO}_{4}\left(\mathrm{bc}_{\mathrm{a}}\right)$ and $0.025 \mathrm{~N}$ $\mathrm{NaOH}\left(\mathrm{bc}_{\mathrm{b}}\right)$ in the way previously applied to aqueous homogenates of leaves ( $\mathrm{Czuchajowska,}$ Przybylski, 1978). Soil dried at $105^{\circ} \mathrm{C}$, sieved as before, was used for the estimation of organic matter content by Tiurin's method, nitrogen content - by that of Kjeldahl and metals content by means of atomic absorption spectroscopy (B a k e r, S mith, 1974) on a Perkin-Elmer 403 spectrometer. In the latter procedure acids extracts $(50 \mathrm{ml})$ of 5 -g samples of soil were applied: $1 \mathrm{~N} \mathrm{H}_{2} \mathrm{SO}_{4}$ and $1 \mathrm{~N} \mathrm{HCl}$ were used for $\mathrm{Zn}_{\mathrm{n}}$ estimation, $0.1 \mathrm{~N} \mathrm{HCl}$ for $\mathrm{Mn}$ and $\mathrm{Fe}$, $0.05 \mathrm{~N} \mathrm{HCl}$ for $\mathrm{Mg}$ and $1 \mathrm{~N} \mathrm{HNO}_{3}$ for $\mathrm{Pb}$ and $\mathrm{Cd}$. Estimation of cadmium involved its concentration in the organic phase of methylisobutyl ketone. 
The dustfall on every area, ranging for the four investigated stands from 160 to $38 \mathrm{t}$ per $\mathrm{km}^{2}$ per year, and its metal content were measured by the sedimentation method ( $\mathrm{Just}, 1963)$ at the level of $2 \mathrm{~m}$ above the surface and at $0.5 \mathrm{~m}$, i.e. that of the dwarf shrub height, during the vegetation period from April to September 1977. The dustfall samples, collected in Weck jars placed under the canopy of three-tops on the mentioned altitudes, after transportation to the laboratory were evaporated to dryness. After estimation of the dry mass, the material was moistened with a few millilitres of the $1: 1$ mixture of concentrated $\mathrm{HCl}$ and $35 \% \mathrm{HNO}_{3}$, evaporated once more to dryness and calcinated in an electric oven at $450-500^{\circ}$ during 3 hours (Strusiński, Wyszyńska, 1971). Subsequen't addition of the $\mathrm{HCl}-\mathrm{HNO}_{3}(3: 1)$ mixture, followed by introduction of $10 \mathrm{ml} \mathrm{H}_{2} \mathrm{O}$, transformed the metals into soluble compounds. The solutions, acidified to $\mathrm{pH}=1$, were then used for estimation of metal content by atomic absorption spectroscopy (see above).

The leaves of Vaccinium myrtillus and Vaccinium vitis-idaea and the current year and biennial needles of Pinus silvestris were collected only once from the described stands in the following manner. From every dwarf shrub, taken out of a hundred specimens randomly chosen, one shoot was collected, containing leaves of all ages. In the case af Pinus silvestris, from every tree of the hundred randomly chosen individuals, one branch cut off from the middle part of the crown, containing current year and biennial needles, was collected. After transportation to the laboratory, the leaves and needles were picked off and thoroughly washed (to eliminate the metals superficially accumulated, the content of which could be easily influenced by disturbing factors, e.g. rainfall). Then the samples, dried to constant weight at $105^{\circ} \mathrm{C}$, were powdered to a homogeneoús material (properly protected against contamination by trace elements). It was subsequently heated at $500-550^{\circ} \mathrm{C}$ to constant weight. The ash obtained was dissolved in $1 \mathrm{~N} \mathrm{HNO}_{3}$ - only for $\mathrm{Mn}$ estimation $20 \% \mathrm{HCl}$ was used - and the content of metals was estimated with an atomic absorption spectrometer (see above). In some cases the solutions had to be suitably diluted.

It should be mentioned that the content of $\mathrm{Pb}, \mathrm{Zn}, \mathrm{Cd}, \mathrm{Mn}, \mathrm{Fe}$ and $\mathrm{Mg}$, expressed in ppm of dry material, was always estimated in 8 separate samples of soil, dustfall, leaves and needles. The results obtained by analysis were evaluated statistically, the correlation indices were calculated according to S n edecor (1956). 
RESULTS

The elements under consideration present in the dustfall (Table 1), accumulated mainly in the top soil layer (0-5 cm, Figs. 1, 2). Lead, zinc and cadmium were found in a particularly high percentage, their content in the deeper layers decreasing distinctly, e.g. for the $\mathrm{K}$ stand, closest to the emitter, the content of $\mathrm{Pb}$ decreased from $2800 \mathrm{ppm}$ in the $0-5 \mathrm{~cm}$ layer to $75 \mathrm{ppm}$ in the subsequent $5-10 \mathrm{~cm}$ layer and finally to $8 \mathrm{ppm}$ in the lowest one. Only the soil from the L stand, characterised by a very high content of organic matter (ca 40\%) showed appreciable concentration of metal in the second layer, 5-10 cm; this concerned $\mathrm{Zn}$ (the element known to form complexes with humic compounds), $\mathrm{Cd}$ and above all $\mathrm{Pb}$, the latter element present in $1060 \mathrm{ppm}$ concentration. The dependence of metal concentration in the polluted upper layer versus the distance to the emitter proved to be almost linear, e.g. the concentration of $\mathrm{Pb}$ decreased from $2800 \mathrm{ppm}$, through $1100 \mathrm{ppm}$ to $130 \mathrm{ppm}$. The control stand showed a concentration of $\mathrm{Pb}, \mathrm{Zn}$ and $\mathrm{Cd}$ of 75,24 and $0.7 \mathrm{ppm}$, respectively. In the upper soil layer from the stand near the emitter (stand $\mathrm{K}$, layer $0-5 \mathrm{~cm}$ ) the $\mathrm{pH}$ increased, as a result of metal accumulation, from 5.4 to 5.8 in the period: April 1977 November 1978. The two more distant stands did not show such a change, the $\mathrm{pH}$ values being contained in the range 4-5, as compared with the $\mathrm{pH}$ of the control area not exceeding $\mathrm{pH}=4$.

Table 1

Content of some metals in the dustfall in 1977

\begin{tabular}{|c|c|c|c|c|c|c|c|c|}
\hline \multirow{2}{*}{ Stand } & \multirow{2}{*}{ Altitude } & \multirow{2}{*}{$\begin{array}{c}\text { Dustfall } \\
\mathrm{t} / \mathrm{km}^{2}\end{array}$} & $\mathrm{~Pb}$ & $\mathrm{Zn}$ & $\mathrm{Cd}$ & $\mathrm{Mn}$ & $\mathrm{Fe}$. & $\mathrm{Mg}$ \\
\hline & & & \multicolumn{6}{|c|}{ (ppm) } \\
\hline \multirow{2}{*}{ K } & $2 \mathrm{~m}$ & 124.47 & 9703 & 20131 & 198.9 & 810 & 22314 & 14067 \\
\hline & $0.5 \mathrm{~m}$ & 165.68 & 7412 & 14972 & 149.7 & 690 & 15713 & 12896 \\
\hline \multirow{2}{*}{$\mathbf{L}$} & $2 \mathrm{~m}$ & 85.9 & 2977 & 5888 & 75.2 & 421 & 9388 & 6215 \\
\hline & $0.5 \mathrm{~m}$ & 64.4 & 3785 & 3955 & 67.8 & 305 & 15198 & 3955 \\
\hline \multirow[t]{2}{*}{ M } & $2 \mathrm{~m}$ & 62.78 & 2086 & 6519 & 97.8 & 600 & 11799 & 9126 \\
\hline & $0.5 \mathrm{~m}$ & 71.47 & 3230 & 8591 & 109.0 & 484 & 9106 & 7560 \\
\hline $\mathrm{C}$ & $2 \mathrm{~m}$ & 37.67 & 273 & 709 & 27.3 & 500 & 7981 & 4775 \\
\hline (control) & $0.5 \mathrm{~m}$ & 55.12 & 316 & 862 & 26.3 & 485 & 5997 & 4208 \\
\hline
\end{tabular}

Accumulation of the investigated metals in the green parts of the plants depended for every considered stand on the plant species. The content of lead in the leaves collected from the most polluted stand $\mathrm{K}$, showed drastic differences. For Vaccinium vitis-idaea $\mathrm{Pb}$ concentration, $2800 \mathrm{ppm}$, exceeded 30-times that in the leaves of Vaccinium myrtillus and 6-times the content in the biennial needles of Pinus silvestris. The 

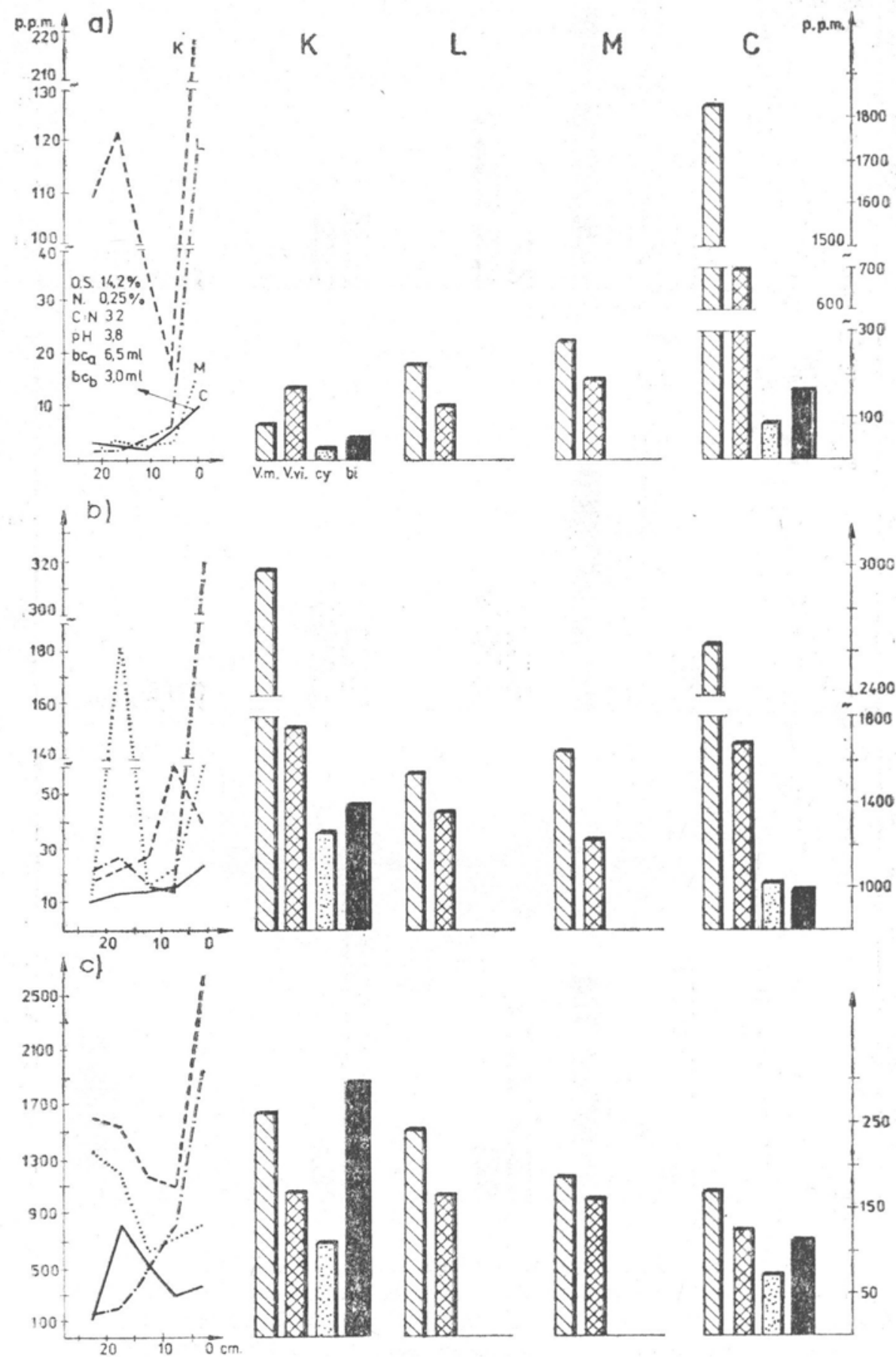

Fig. 2. Content of: (a) manganese, (b) iron, (c) magnesium (ppm) in five soil layers and in the leaves of the investigated species. For other explanations see Fig. 1. 
concentration of zinc was lower, however, Vaccinium vitis-idaea accumulated 4-times more of this element than did Vaccinium myrtillus. Cadmium was accumulated to the highest degree by Vaccinium myrtillus $(7 \mathrm{ppm})$ growing in the stand near the emitter. It is characteristic that the predominance of some heavy metals concentration in Vaccinium vitis-idaea over Vaccinium myrtillus (Figs. 1, 2) diminishes with increasing distance from the emitter, this concerning $\mathrm{Pb}, \mathrm{Zn}$ and $\mathrm{Mn}$. Concentration of $\mathrm{Cd}, \mathrm{Mg}$ and $\mathrm{Fe}$ was always higher in Vaccinium myrtillus than in Vaccinium vitis-idaea, however, the content of the latter metal showed only limited difference for the three investigated species in respect to the distance.

A significant positive correlation was found between the content of $\mathrm{Pb}, \mathrm{Zn}$ and $\mathrm{Cd}$ in the soil and their concentration in the leaves of both Vaccinium species. The respective values for Vaccinium myrtillus are as follows: $\mathrm{Zn} 0.86^{* *}, \mathrm{~Pb} \mathrm{0.94**}, \mathrm{Cd} 0.65^{* *}$; for Vaccinium vitis-idaeu: $\mathrm{Zn} 0.90^{* *}, \mathrm{~Pb} \mathrm{0.98^{** }}$, Cd $0.91^{* *}$ (the index ${ }^{* *}$ denotes the level of significance equal to 0.01). Manganese behaved differently from all other metals. Its uptake by the three species was independent of $\mathrm{Mn}$ concentration in the soil and in the dustfall. The lowest concentration of manganese was found in the soil of the control stand, in which all species accumulated many times more manganese than in the three polluted stands. Mn concentration in the leaves of Vaccinium myrtillus (1900 ppm), exceeded almost 3-times that found in the leaves of Vaccinium vitis-idaea and 20-times that in the current year needles of Pinus silvestris (Fig. 2a). Along with the gradually decreasing distance from the emitter, the uptake of $\mathrm{Mn}$ by the same species decreased, reaching very low values near the zinc-plant. Statistical calculations showed a significant, negative correlation between $\mathrm{Mn}$ content in the soil and leaves of both Vaccinium species: $-0.42^{*}$ and $-0.35^{*}$ for myrtillus and vitis-idaea, respectively (the level of significance equal to 0.05). Although analysis on manganese content in Pinus silvestris leaves was performed only for the most polluted stand $\mathrm{K}$, and the control one $\mathrm{C}$, it seems obvious that the negative correlation is also typical for this species.

\section{DISCUSSION}

Confrontation of the results presented above with a few literature data is really difficult because of the differences, or even neglection in some papers of such parameters as soil characteristics, the amount of industrial emission, etc. The obtained data concerning the content of $\mathrm{Fe}$ and $\mathrm{Mg}$ in the leaves of Vaccinium species and Pinus silvestris, are in general similar to the mean values calculated from the data of $\mathrm{W}$ i e l- 
golaski et al., (1975) and Huttunen (1975), for the same species grown in the forests of Norway and Finland. This leads to the conclusion that the content of $\mathrm{Mg}$ in plants, and particularly that of $\mathrm{Fe}$ remains at a constant level for any particular species, even in different climatic-edaphic conditions (see also Eaton, M echan, 1971).

This is not true in respect to $\mathrm{Pb}, \mathrm{Zn}$ and $\mathrm{Cd}$. For instance the concentration of $\mathrm{Pb}$ in the two Vaccinium species exceeded several times that found by Lâg and Bolviken (1974) in Vaccinium species grown in natural galena soils, $\mathrm{Zn}$ content also appeared to be two-times higher than that found by Kazimierczakowa (1975) for Vaccinium vitis-idaea growing on a pollution-free area. The amounts of $\mathrm{Cd}$ found in the leaves of Vaccinium myrtillus and Pinus silvestris were also several times higher than those estimated by Lâg and Bolviken (1974). The distinct differences in leaf morphology of the two investigated Vaccinium species (apart from those of Pinus silvestris) cannot be considered as the only important reason of different ability of heavy metal accumulation, because the ratio of a considered metal concentration in Vaccinium vitis-idaea to that in Vaccinium myrtillus showed distinct changes depending on the distance from the source of emission, i.e. on metal content in the dustfall and in the soil (this concerned, first of all, $\mathrm{Pb}, \mathrm{Zn}, \mathrm{Cd}$ and $\mathrm{Mn}$ ). To what degree an assimilating organ shows a different ability of accumulating different metals over a longer period of time, is clearly shown by comparison of the current year and biennial needles of Pinus silvestris. The needles older by one year accumulated $250 \%$ and $200 \%$ more lead and iron, respectively, than did the youngest ones, however, only $20-50 \%$ more $\mathrm{Zn}, \mathrm{Cd}$ and $\mathrm{Mg}$.

It is necessary to point out that heavy metals contamination of a plant is not always reflected in changes of its life activity, as shown by $\mathrm{Czuchajowska,} \mathrm{Strączek} \mathrm{(1979)} \mathrm{in} \mathrm{respect} \mathrm{to} \mathrm{the} \mathrm{germina-}$ tion viability of Vaccinium species seeds, and by Buszman (1979) - as regards the flowering phenomenon of these species.

Manganese seems to a large extent an antagonist in respect to the other metal elements considered in this paper. The individual features of the species strongly influenced its accumulation. It is remarkable that the leaves of Vaccinium myrtillus grown in the relatively pollution-free stand $\mathrm{C}$ accumulated 20 -times more of $\mathrm{Mn}$ than the leaves collected from the stands influenced by the zinc-plant. These amounts are 5-times higher than those observed by Wielgolaski et al. (1975). On the other hand, the data for Vaccinium vitis-idaea growing in the control stand do not deviate from those obtained by the mentioned authors. The substantial differences in manganese accumulation in the green parts of plants originating from the same stand make it necessary to consider whether the data concerning the values of $\mathrm{pH}$ and the buffer 
capacity of homogenates of leaves ( $\mathrm{Czu}$ c ha jowska, Przybylski, 1978; Czuchajowska, 1979) are responsible among other factors for the high degree of $\mathrm{Mn}$ accumulation in Vaccinium myrtillus leaves as compared with those of Pinus silvestris (Fig. 2a), because of the well known dependence of manganese mobility on the $\mathrm{pH}$ of the medium. One should mention here that the latter factors are related to the redox potentials which influence manganese binding to chloroplasts previously treated with some chemicals, as $\mathrm{Takahashi}$ and Asad a (1977) have noticed recently.

Less manganese accumulation in Vaccinium plants in heavily polluted stands may result from the difficulty of its transport to the aerial parts from the roots. This may be caused by the antagonistic character of $\mathrm{Mn}$ in respect to $\mathrm{Pb}$ and $\mathrm{Cd}$. The latter two metals occur in high concentration in Vaccinium roots (Lorek, 1978), for which a highly positive correlation between the content of $\mathrm{Mn}$ and that of $\mathrm{Pb}, \mathrm{Zn}$ and $\mathrm{Cd}$ has already been found.

\section{Acknowledgment}

The authors are grateful to Doc. Dr hab. T. Przy by lski from the Silesian University, for helpful discussions.

\section{REFERENCES}

Buszman B., 1979. Phenological changes of Vaccinium myrtillus L. and Vaccinium vitis-idaea L. caused by industrial emissions, Materials of the IV th Scientific Session of the Naturalists of Silesia. Katowice, October 1979 (in Polish, in print).

Baker A. S., S mith R. L., 1974. Preparation of solution for atomic absorption analyses of iron, manganese, zinc and copper in plant tissue. J. Agr. Food Chem. 22: 103.

Czuchajowska Z., 1979. Seasonal changes of $\mathrm{pH}$ and buffer capacity of aqueous homogenates of Vaccinium vitis-idaea and Vaccinium myrtillus leaves. Acta Soc. Bot. Pol. 48: 35-46.

Czuchajowska Z., Przybylski T., 1978. Seasonal changes of acidity and buffer capacity of aqueous homogenates of Pinus silvestris needles and the influence of zinc-plant immisions. Bull. Acad. Pol. Sci. Cl. 2 26: 361-368.

$\mathrm{Czuchajowska} \mathrm{Z.,} \mathrm{Strączek} \mathrm{T.,} \mathrm{1979.} \mathrm{The} \mathrm{influence} \mathrm{of} \mathrm{zinc-plant} \mathrm{emissions}$ on germination viability and survival rates of the seeds of Vaccinium species. Materials of the IV ${ }^{\text {th }}$ Scientific Session of the Naturalists of Silesia. Katowice, October 1979 (in Polish, in print).

Dorn C. R., Pierce J. O., Phillips P. E., Chase G. R., 1976. Airborn Pb, $\mathrm{Cd}$ and $\mathrm{Cu}$ concentration by particle size near a $\mathrm{Pb}$ smelter. Atmosph. Envir. 10: 443-446.

Eat on G. W., Mechan C. N., 1971. Effects of leaf position and sampling data on leaf nutrient composition of eleven highbush bluberry cultivars. J. Am. Soc. Hort. Sci. 96: 379-380.

Huttunen S., 1975. The influence of air pollution on the forest vegetation 
around Oulu. Acta Univ. Oulensis, ser. A no. 33, Biologica 2; (I) 1-18, (II) 1-37, (III) 1-24.

John M. K., van La erhoven C. J., Cross C. H., 1975. Cadmium, lead and zinc accumulation in soils near a smelter complex. Environ. Lett. 10: 25-30. J u s t J., 1963. Methodics of sanitary investigation of the atmospheric air. Biuletyn SANEPID no. 1 (in Polish).

$\mathrm{Kaz}$ imierczakowa R., 1975. Correlation between the amount of industrial dust fall and the lead and zinc accumulation in some plant species. Bull. Acad. Pol. Sci. Cl. 2 23: 611-621.

Lâg J., Bolviken I., 1974. Some naturally heavy metal poisoned areas of interest in prospecting, soil chemistry and geomedicine. Jordungerskelsens Saertrykk, Norges geologiske inderskelse 202: 73-96.

L o r e k E., 1978. Investigations of chemical composition of the fruits of bilberry Vaccinium myrtillus L., and Vaccinium vitis-idaea L. as indicator of the degree of environment pollution in a highly industrialized region. $\mathrm{Ph}$. D. Thesis, Library of Uniwersytet Sląski, Katowice (in Polish).

S nedecor G. W., 1956. Statistical methods. Iowa State University Press, Iowa, p. 535 .

Strusiński A., Wyszyńska H., 1971. Estimation of iron, copper, zinc and lead in atmospheric air. Roczniki PZH 22: 649-656 (in Polish).

Takahashi M., Asada K., 1977. Manganése binding to sodium cyanide-treated chloroplasts: Effects of light and redoxpotentials on the binding. Plant Cell Physiol. 18: 807-814.

Wielgolaski F. E., Kjelvik S., Kallio P., 1975. Mineral content of tundra and forest tundra plants in Fennoscandia. Analysis and synthesis. Fennoscandia Tundra Ecosystems Part 1, 16: 317-332.

\section{Kumulowanie się metali ciężkich $w$ ekosystemie pozostającym pod wptywem emisji huty cynku}

Streszczenie

Zbadano zawartość $\mathrm{Pb}, \mathrm{Zn}, \mathrm{Cd}, \mathrm{Mn}, \mathrm{Fe}$ i $\mathrm{Mg}$ w liściach Pinus silvestris, Vaccinium myrtillus i Vaccinium vitis-idaea, stanowiących główne składniki wybranego ekosystemu znajdującego się $\mathrm{w}$ bezpośrednim sąsiedztwie huty cynku w Miasteczku Sląskim (stanowiska K, L i M odległe w kierunku przeważających wiatrów, odpowiednio, o $0,92,5$ i $5,0 \mathrm{~km}$; stanowisko kontrolne C - w odległości $24 \mathrm{~km})$. Oznaczono także zawartość wymienionych metali w pięciu warstwach gleby o podanej charakterystyce, a także w pyłach przemysłowych na poziomie 0,5 i $2 \mathrm{~m}$ (tab. 1). Gromadzenie się metali w liściach okazało się dla każdego hadanego stanowiska zależne od gatunku rośliny, np. stężenie $\mathrm{Pb}$ w Vaccinium vitis-idaea $(\mathrm{K}), 2800$ ppm, przekraczało 30-to krotnie stężenie w Vaccinium myrtillus i 6-cio krotnie w jednorocznych szpilkach Pinus silvestris. Przewaga stężenia $\mathrm{Pb}, \mathrm{Zn}$ i Mn w liściach Vaccinium vitis-idaea nad ich zawartością w Vaccinium myrtillus zmniejszała się $\mathrm{w}$ miarę oddalania od emitora. Znaleziono znaczącą dodatnią korelację pomiędzy zawartością $\mathrm{Pb}, \mathrm{Zn}$ i Cd $\mathrm{w}$ glebie, a ich stężeniem w liściach; korelacja taka dla Mn okazała się ujemna. Antagonistyczny charakter Mn w stosunku do innych badanych pierwiastków znalazl także odbicie w zmniejszającej się kumulacji tego metalu w liściach $\mathrm{w}$ miarę zbliżania się do emitora (rys. 2a), co prawdopodobnie wynika $\mathrm{z}$ utrudnienia jego przewodzenia $\mathrm{z}$ korzeni do liści, związanego $\mathrm{z}$ dużym stężeniem $\mathrm{Pb}$ i Cd $\mathrm{w}$ korzeniach Vaccinium species. 